\title{
Floral Aromatics of Ptelea: Chemical Identification and Human Response
}

\author{
Anna J. Talcott Stewart \\ Department of Horticulture, Iowa State University, Ames, IA 50011 \\ Terri Boylston and Lester Wilson \\ Department of Food Science and Human Nutrition, Iowa State University, Ames, IA 50011 \\ William R. Graves \\ Department of Horticulture, Iowa State University, Ames, IA 50011
}

\begin{abstract}
AdDiTIONAL INDEX WORDS. aromatic compounds, fragrance, gas chromatography, mass spectrometry, nursery crops
Abstract. Many members of the citrus family (Rutaceae) are valued for the aromatic compounds emitted by their flowers. Ptelea species are unusually cold-hardy members of the Rutaceae, but conflicting descriptions of the fragrance of their unisexual flowers may discourage the use of these trees. We analyzed floral volatiles and human response to these chemicals to test the hypothesis that the fragrance of staminate and pistillate flowers of these species differs. Gas chromatography and mass spectrometry showed that most volatile chemicals emitted by flowers of Ptelea trifoliata and Ptelea crenulata are monoterpenes, sesquiterpenes, and esters. Most volatiles were emitted from flowers of both sexes, but ethyl benzoate and estragole were emitted only from pistillate flowers. When concentrations of aromatics differed between sexes, they were higher for pistillate flowers, except for cis-3-hexenyl butanoate and an unidentified terpene. For $P$. crenulata and $P$. trifoliata, respectively, $81 \%$ and $77 \%$ of survey responses were from volunteers who liked the fragrance. Panelists most frequently described the scent of flowers of $P$. crenulata of both sexes with the words citrus, lime, and sweet. Panelists distinguished between pistillate and staminate flowers of $P$. trifoliata, describing the odor of pistillate flowers most frequently with the words damp-earthy, spicy, and sweet; staminate flowers were perceived as light, fresh, grassy, and pleasant. This work represents the first analysis of floral volatiles of $P$. crenulata and resolves conflicting prior reports regarding the floral fragrance of $P$. trifoliata. We conclude that differences among people rather than the sex of flowers account for conflicting prior reports of floral fragrance. The scents of flowers of $\boldsymbol{P}$. crenulata and $\boldsymbol{P}$. trifoliata appeal to most people and are horticultural assets of these trees.
\end{abstract}

Fragrance is a major horticultural feature of ornamental plants (Giovannini et al., 2021). For example, consumers of rose bushes (Rosa) rated fragrance as more important than any other attribute except disease resistance (Waliczek et al., 2018). Since the 18th century, the North American species, Ptelea trifoliata (Rutaceae), has been used in England and Scotland as an ornamental shrub; however, it is rarely planted in North America, perhaps, in part, due to confusion about the floral fragrance (Harvey, 1981; Lancaster, 1995). Some have reported a strong citrus aroma (Nokes, 2001; Wasson, 2001), and Knuth (1908) reported that male inflorescences have a stronger hyacinth-like scent than do females. In contrast, some claim the odor is unpleasant and have likened it with the scent of a bobcat (Elmore and Janish, 1976; Kurz, 1997). The foliage of $P$. crenulata is also described as illsmelling (McMinn, 1989). Given these disparate reports, it is possible that humans differ in their perception of the aromatic chemicals emitted from flowers of Ptelea.

Received for publication 13 Aug. 2021. Accepted for publication 21 Sept. 2021.

Published online 3 December 2021.

We thank Evan Stewart, Jackie Borseth, Zachary Hudson, J. Austin Gimondo, Laura Irish, and Andrew Bovenmyer for helping prepare materials for sensory panels.

A.J.T.S. is the corresponding author. E-mail: atalcott@iastate.edu.

This is an open access article distributed under the CC BY-NC-ND license (https://creativecommons.org/licenses/by-nc-nd/4.0/).
Although horticultural attention has focused on $P$. trifoliata, commonly known as hop tree or wafer ash, the genus includes two other species, P. crenulata and Ptelea aptera (Yang and Applequist, 2015). P. trifoliata comprises five subspecies that occur across much of North America from Ontario to Florida and as far west as Nebraska and Arizona (Bailey, 1962; Yang and Applequist, 2015). P. crenulata is endemic to California, and $P$. aptera to Baja California (Yang and Applequist, 2015). The leaves of $P$. trifoliata are eaten by larvae of giant swallowtail butterflies (Papilio cresphontes) and grasshoppers (Scistocerca emarginata) (Scriber and Dowell, 1991; Sword and Dopman, 1999). The larvae of the moths Agonopterix pteleae and Agonopterix costimacula feed exclusively on $P$. trifoliata in Illinois (Harrison and Berenbaum, 2005). The flowers attract a variety of insect families as well (Ambrose et al., 1985; Stewart, 2021).

Fragrance frequently alerts insects to floral nectar or pollen rewards, and aromatics may trick insects by mimicking insect sex pheromones (Schiesti et al., 1999; Schiesti and Ayasse, 2001). Floral fragrance may be the most important way that a flower attracts bees, because odor is a much easier identifier for bees to learn than are color and shape (Menzel et al., 1974; Schnetter, 1972). The chemicals most responsible for the attraction of insects may not be the most abundant. For instance, panisaldehyde accounts for only $0.5 \%$ of the fragrance blend of Cirsium arvense, but is an important attractant for pollinators (Theis, 2006). 


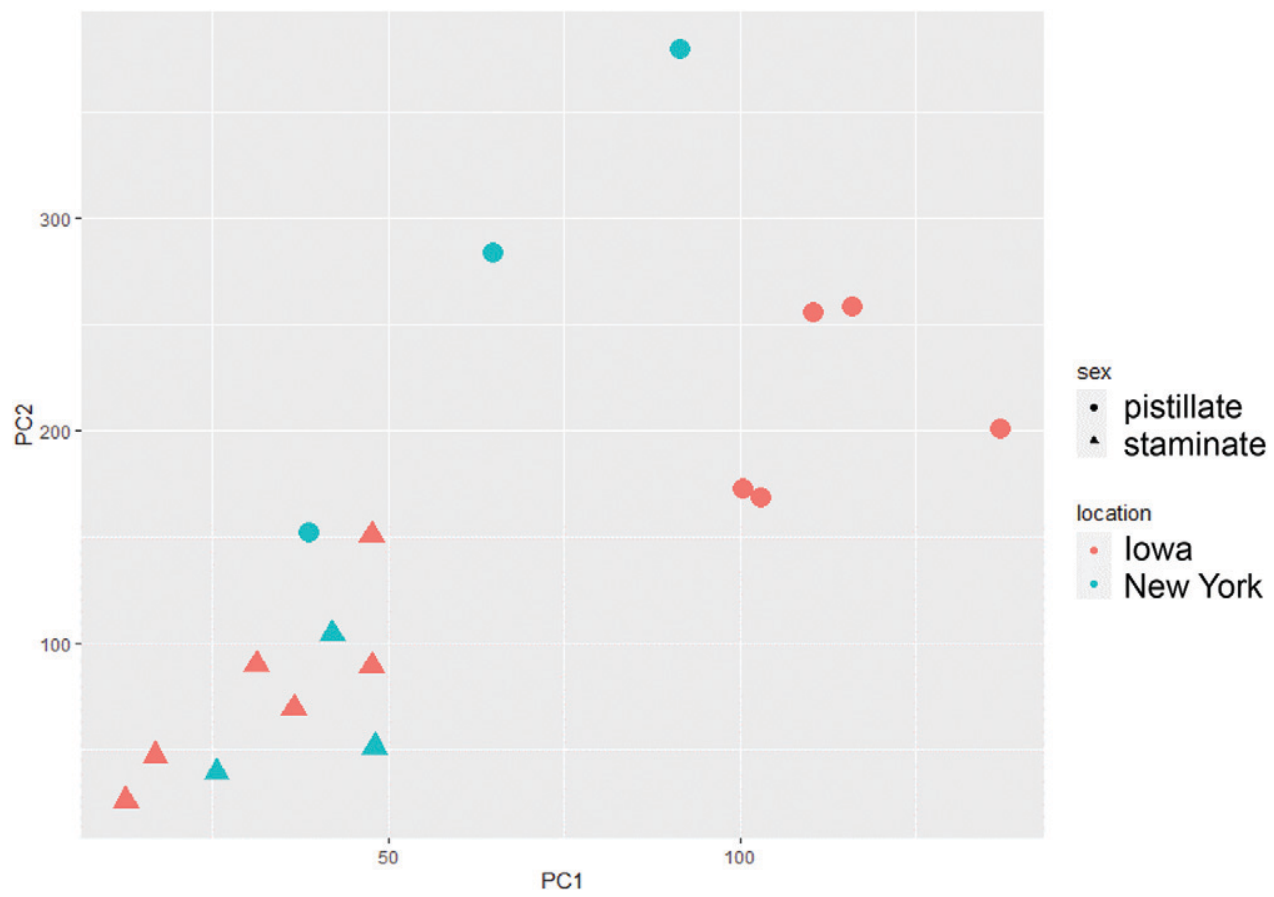

Fig. 1. Principal component analysis (PCA) was used to give an overall summary of the variance between the floral sexes and locations using all the chemicals predicted. The data were expressed as a set of indices called principal components (PC), which each explain a portion of the total variance in the data set. PC1 and PC2 show aroma compound differences between pistillate and staminate flowers of Ptelea trifoliata from gas chromatography. Location (Ames and New York) is marked by color.

Phenolics and terpenes are major groups of secondary metabolites present in plant fragrances. Phenolic compounds arise from the shikimic acid pathway. Simple carbohydrates from glycolysis and the pentose phosphate pathway are converted into phenylalanine, tyrosine, and tryptophan, which, in turn, form all the phenolic compounds (Herrmann and Weaver, 1999). There are two main biosynthetic pathways that produce aromatic terpenoids in plants, the mevalonic acid pathway and the methylerythritol phosphate pathway (Lichtenthaler, 1998). Terpenes primarily act as herbivore deterrents, whereas different phenolic compounds can deter herbivores and pathogens, attract pollinators and fruit dispersers, and absorb ultraviolet radiation (Gershenzon and Croteau, 1992; Taiz and Zeiger, 2010).

P. trifoliata blooms in late May to June in Iowa, and P. crenulata blooms in April (Ambrose et al., 1985; Dirr, 1998). This dioecious species has small greenish-white pistillate and creamy-white staminate flowers that form rounded inflorescences (Ambrose et al., 1985). As Ambrose et al. (1985) describe P. trifoliata, flowers of both species have a corolla composed of five, slightly pointed petals that give the flower an open, shallow-bowl shape.

Pistillate and staminate flowers of dioecious species may have different scent profiles. Staminate flowers of the perennial herb Silene latifolia emit more fragrance than do its pistillate flowers (Waelti et al., 2009). Several compounds were present only in either the pistillate or staminate flowers of three dioecious figs: Ficus fistulosa, Ficus fulva, and Ficus punctata (Grison et al., 1999). Staminate and pistillate flowers of Laurus nobilis had mostly similar compounds, although in slightly different percentages; however, linalool and its oxides, which made up $7.1 \%$ of the profile, were emitted only from staminate flowers (Flamini et al., 2002).
Although showy flowers, cold hardiness, and advantages for native insects are important horticultural traits; further investigation of floral fragrance was necessary for evaluating the ornamental potential of Ptelea. We sought to determine if pistillate and staminate flowers of $P$. crenulata and $P$. trifoliata differ in the aromatic chemicals they emit. We hypothesized that such differences explain that both highly favorable and negative descriptions of the scent of these flowers have been reported. An alternative hypothesis is that the range of descriptions is due to variation in perception among people. To investigate fragrance composition and perception, chemical analyses with gas chromatography and mass spectrometry and two types of sensory panels were used. A descriptive panel showed how people describe the fragrance, and an affective test demonstrated preferences among human respondents.

\section{Materials and Methods}

\section{Volatile analysis}

SAMPLING. Inflorescences of $P$. trifoliata were collected from a wooded area of Ames, IA, and at Evangola State Park in Irving, NY (with permission), in May and June 2018 and 2019. At least three staminate and three pistillate plants were sampled in both states during both years. Inflorescences of $P$. crenulata were collected with permission from Black Diamond Mines Regional Preserve at Antioch, CA, in Apr. 2018. Sampled inflorescences ranged from those with flowers with buds beginning to open to flowers at anthesis, with no flowers that had begun to senesce. Samples were kept hydrated during transport to a laboratory for analysis within $24 \mathrm{~h}$ of collection.

Gas CHROMATOGRAPHY AND MASS SPECTROMETRY. Samples of flowers and attached inflorescence pedicels (no leaves) weighing 
Table 1. Principal component analysis (PCA) was used to give an overall summary of the variance between the floral sexes and locations using all the chemicals predicted. The data were expressed as a set of indices called principal components (PCs), which each explain a portion of the total variance in the data set. Cumulative variance explained by the first four PCs was used to assess differences in aroma profiles between floral sex and location of Ptelea trifoliata. Aromatic compounds, organized by chemical category, that contributed at least $4 \%$ to the first four PCs are included in the table. Because PC percentages less than $4 \%$ are not included, the total percent for each PC column is less than $100 \%$.

\begin{tabular}{|c|c|c|c|c|c|c|}
\hline \multirow{2}{*}{\multicolumn{3}{|c|}{ Cumulative variance explained }} & \multirow{2}{*}{$\begin{array}{c}\mathrm{PC} 1(\%) \\
36.1\end{array}$} & \multirow{2}{*}{$\frac{\mathrm{PC} 2(\%)}{58.8}$} & \multirow{2}{*}{$\begin{array}{c}\mathrm{PC} 3(\%) \\
72.5\end{array}$} & \multirow{2}{*}{$\begin{array}{c}\text { PC4 (\%) } \\
80.3\end{array}$} \\
\hline & & & & & & \\
\hline Chemical category & $\begin{array}{l}\text { Retention } \\
\text { index }\end{array}$ & Compound & & & & \\
\hline Benzenoid & 1024 & Benzene, 1-methoxy-4-methyl & & & & 7.1 \\
\hline Benzenoid & 1195 & Estragole & & 6.2 & & \\
\hline Cyclic ketone & 1395 & (Z)-jasmone & 5.2 & & & \\
\hline Ester - aliphatic & 1004 & (Z)-3-hexenyl acetate & & & & 5.0 \\
\hline Ester - aliphatic & 1118 & 2-hexenyl, propanoate & & & 6.6 & \\
\hline Ester - aliphatic & 1161 & 2-hexenyl butanoate & & 8.1 & & \\
\hline Ester - aliphatic & 1184 & cis-3-hexenyl butanoate & & & & 4.0 \\
\hline Ester - aliphatic & 1325 & $\begin{array}{l}\text { cis-hex-3-en-1-yl 2-methylbut-2- } \\
\text { enoate }\end{array}$ & 4.5 & & & \\
\hline Ester - aliphatic & 1218 & cis-3-hexenyl-methylbutanoate & & & & 14.0 \\
\hline Ester - aliphatic & 1245 & $\begin{array}{l}\text { trans-2-hexenyl-3- } \\
\text { methylbutanoate }\end{array}$ & & & 6.5 & \\
\hline Ester - aromatic & 1171 & Ethyl benzoate & & & & 10.5 \\
\hline Ester - aromatic & 1193 & Methyl salicylate & & & 5.7 & \\
\hline Ester - aromatic & 1341 & Methyl 2-methoxybenzoate & 4.7 & & & \\
\hline Phenylpropanoid & 1285 & trans-anethole & & & 4.2 & \\
\hline Phenylpropanoid & 1317 & cis-anethole & & 4.1 & & \\
\hline Phenylpropanoid & 1358 & Eugenol & & 4.0 & & \\
\hline Phenylpropanoid & 1401 & Methyleugenol & 5.3 & & & \\
\hline Terpene & 1124 & E-4,8-dimethylnona-1,3,7-triene & & 7.3 & & \\
\hline Terpene & 1392 & Unidentified, MW 204 & & 7.9 & & \\
\hline $\begin{array}{l}\text { Terpene - } \\
\text { monoterpene }\end{array}$ & 975 & Sabinene & & 4.3 & & \\
\hline $\begin{array}{l}\text { Terpene - } \\
\text { monoterpene }\end{array}$ & 989 & $\beta$-myrcene & & 6.6 & & \\
\hline $\begin{array}{l}\text { Terpene - } \\
\text { monoterpene }\end{array}$ & 1030 & $\beta$-phellandrene & & 4.8 & & \\
\hline $\begin{array}{l}\text { Terpene - } \\
\text { monoterpene }\end{array}$ & 1038 & trans- $\beta$-ocimene & 4.1 & & & \\
\hline $\begin{array}{l}\text { Terpene - } \\
\text { monoterpene }\end{array}$ & 1048 & cis- $\beta$-ocimene & & & 5.4 & \\
\hline $\begin{array}{l}\text { Terpene - } \\
\text { monoterpene }\end{array}$ & 1099 & Linalool & & 6.1 & & \\
\hline $\begin{array}{l}\text { Terpene - } \\
\text { monoterpene }\end{array}$ & 1134 & $\begin{array}{c}\text { 2,6-dimethyl-1,3,5,7- } \\
\text { octatetraene, E,E- }\end{array}$ & & & 5.1 & \\
\hline $\begin{array}{l}\text { Terpene - } \\
\text { monoterpene }\end{array}$ & 1142 & 1,3,8-p-menthatriene & 4.0 & & & \\
\hline $\begin{array}{l}\text { Terpene - } \\
\text { sesquiterpene }\end{array}$ & 1351 & $\alpha$-cubebene & 5.4 & & & \\
\hline $\begin{array}{l}\text { Terpene - } \\
\text { sesquiterpene }\end{array}$ & 1370 & $\alpha$-ylangene & & & & 15.6 \\
\hline $\begin{array}{l}\text { Terpene - } \\
\text { sesquiterpene }\end{array}$ & 1384 & $\beta$-bourbonene & 3.9 & & & \\
\hline $\begin{array}{l}\text { Terpene - } \\
\text { sesquiterpene }\end{array}$ & 1390 & $\beta$-elemene & 4.2 & & & \\
\hline $\begin{array}{l}\text { Terpene - } \\
\text { sesquiterpene }\end{array}$ & 1420 & Caryophyllene & & & 6.4 & 4.2 \\
\hline $\begin{array}{l}\text { Terpene - } \\
\text { sesquiterpene }\end{array}$ & 1428 & $\gamma$-elemene & 4.7 & & & \\
\hline
\end{tabular}




\begin{tabular}{|c|c|c|c|c|c|c|}
\hline & & & PC1 $(\%)$ & PC2 (\%) & PC3 $(\%)$ & PC4 (\%) \\
\hline \multicolumn{3}{|c|}{ Cumulative variance explained } & 36.1 & 58.8 & 72.5 & 80.3 \\
\hline $\begin{array}{l}\text { Terpene - } \\
\text { sesquiterpene }\end{array}$ & 1433 & $\beta$-ylangene & 4.5 & & & \\
\hline $\begin{array}{l}\text { Terpene - } \\
\text { sesquiterpene }\end{array}$ & 1504 & $\alpha$-farnesene & & & 5.7 & \\
\hline \multirow{6}{*}{$\begin{array}{l}\text { Terpene - } \\
\text { sesquiterpene }\end{array}$} & 1523 & $\delta$-cadinene & & & 4.3 & \\
\hline & 1208 & Unidentified & 4.9 & & & \\
\hline & 1211 & Unidentified & 4.9 & & & \\
\hline & 1362 & Unidentified & & & & 6.5 \\
\hline & 1365 & Unidentified & 4.6 & & & \\
\hline & 1415 & Unidentified & 4.7 & & & \\
\hline
\end{tabular}

$0.75 \mathrm{~g}$ were sealed in $100-\mathrm{mL}$ glass bottles with polytetrafluoroethylene septa. Bottles were placed into a water bath for $50 \mathrm{~min}$ at $40^{\circ} \mathrm{C}$ to enhance the release of volatiles into the headspace onto a solid phase microextraction (SPME) fiber $[2 \mathrm{~cm}-50 / 30 \mu \mathrm{m}$ divinyl benzene/carboxen/polydimethylsiloxane (StableFlex; Supelco, Bellafonte, PA)]. Analyses of volatile compounds were conducted on a gas chromatograph (GC) equipped with a splitless injection port and flame ionization detector (HewlettPackard 6890; Agilent Technologies, Santa Clara, CA). Volatiles were thermally desorbed $\left(220^{\circ} \mathrm{C}\right)$ for $3 \mathrm{~min}$ via the $\mathrm{GC}$ injection port onto a fused-silica capillary column $[30 \mathrm{~m} \times 0.25 \mathrm{~mm} \times$ $0.25 \mu \mathrm{m}$ film thickness (SPB-5, Supelco)]. The column pressure was set at $124.0 \mathrm{kPa}$ with a helium flow rate of $1.9 \mathrm{~mL} \cdot \mathrm{min}^{-1}$. The oven temperature was held at $30^{\circ} \mathrm{C}$ for 5 min and increased to $200^{\circ} \mathrm{C}$ at a rate of $5^{\circ} \mathrm{C} \cdot \mathrm{min}^{-1}$ and held for $10 \mathrm{~min}$. Flow rates of detector gases were air at $400 \mathrm{~mL} \cdot \mathrm{min}^{-1}$ and hydrogen at $30 \mathrm{~mL} \cdot \mathrm{min}^{-1}$. Volatile compounds were predicted using Kovats retention indices from aroma databases and GC-mass spectrometry (MS) analysis (Acree and Arn, 2004; Flavor \& Extract Manufacturers Association, 2021). Quantitation of the volatile compounds was based on peak areas, which are responses from the flame ionization detector. It is worth noting that the condition of the flowers analyzed with GC was different from the flowers in the sensory panels because the GC flowers were heated to a higher temperature in the water bath.

GC-MS was performed on a GC (7890B GC/5977A MS; Agilent Technologies) with a mass selective detector. The GC conditions were the same as for chromatographic analyses. Mass-spectrometer conditions were set as follows: electron ionization positive $(\mathrm{EI}+)$ polarity, source electron ionization energy at $70 \mathrm{eV}$, MS source temperature at $230^{\circ} \mathrm{C}$, quadrupole temperature at $150^{\circ} \mathrm{C}$, and scan range from $\mathrm{m} / \mathrm{z} 41$ to 400 , at a frequency scanning cycle of six scans/s. Mass of spectra of the volatile compounds was compared with a spectral library (MassHunter version B.07.00.1413, Agilent Technologies).

\section{Sensory analysis}

After gaining approval from the institutional Human Subjects Review Committee of our Institutional Review Board in 2018 and 2019, volunteer panelists at least 18 years old were recruited to assess human response to floral fragrance of $P$. trifoliata and $P$. crenulata. Although demographic information about panelists was not recorded, they varied in age, gender, and race. Flowers of the two species were collected in Iowa and California and transported to a laboratory, as described, for analysis of volatile chemicals.

DesCRIPTIVE TEST. The goal of this analysis was to generate a list of descriptive words human subjects would choose to use to describe the floral scents of $P$. trifoliata and $P$. crenulata (Cairncross and Sjöström, 1950; Stone et al., 1974). Separated by species and sex, five or six flowers from an inflorescence at anthesis and not showing signs of senescence were placed into a $200-\mathrm{mL}$ glass jar surrounded with aluminum foil with the opening covered with cheese cloth and a plastic lid; this allowed panelists to smell the flowers at the proper time without seeing the flowers. Leaves and as much of the peduncle as possible were eliminated from samples to limit investigation to floral fragrance, not that of vegetative parts. Flowers equilibrated in the jars $30 \mathrm{~min}$ to $1 \mathrm{~h}$ before the session. Fifteen volunteers participated in the test with P. crenulata in Apr. 2018 and 12 in the test with P. trifoliata in June 2018. At the initial session, each panelist received two jars: one containing staminate flowers and one containing pistillate flowers. On cue, panelists uncapped the jar containing the staminate flowers, sniffed them, and wrote down words describing the fragrance. Panelists then shared their words with one another and had an opportunity to discuss which of their collective words conveyed the same meaning so that synonymous or nearduplicate words could be eliminated. Because panelists might perceive the fragrance differently, agreement was not the goal of the discussion. Rather, the goal was to develop a collection of words that represented the perceptions of all panelists. Then the process was repeated with the pistillate flower. Researchers did not suggest any vocabulary to panelists.

In a second session 1 or $2 \mathrm{~d}$ later, the same panelists (15 in Apr., 12 in June 2018) participated in a test session in individual sensory booths. Each panelist received the six sample jars prepared as before with letter labels in a random order. Two contained pistillate flowers, two staminate flowers, and two were empty as a control. Panelists were given a list of the vocabulary words they had agreed upon at the first session to describe the scent. For each jar, they were given 2 min to remove the plastic lid, sniff, and choose the vocabulary words that best described the fragrance.

AfFective Test. An additional 119 panelists for $P$. crenulata and 111 for $P$. trifoliata were recruited to smell both pistillate and staminate flowers and give their opinion of the floral 


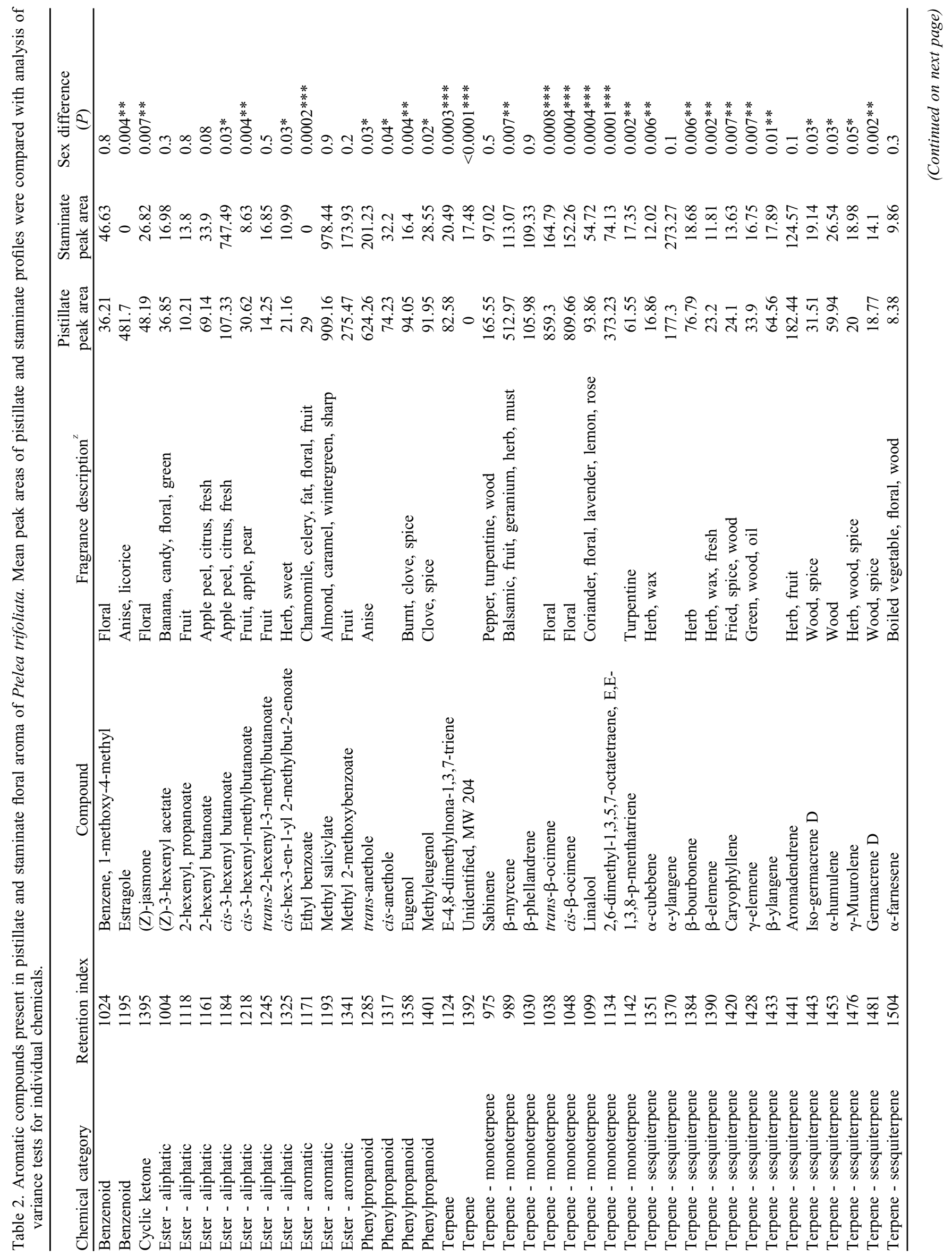




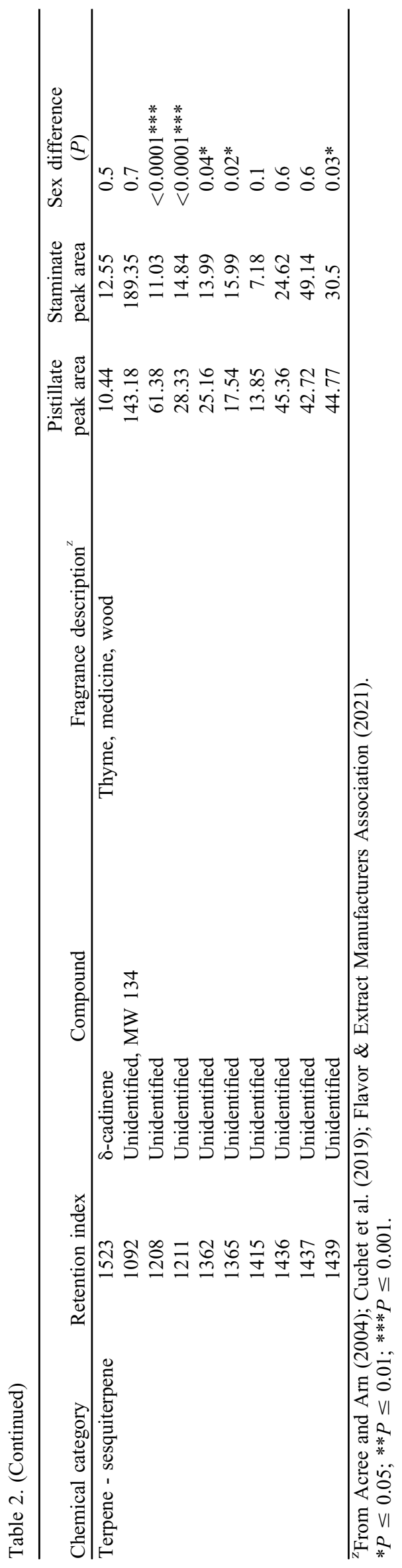

fragrance (Lim, 2011). Inflorescences, with their flowers mostly at anthesis, had all leaves removed to focus panelist attention on the floral fragrance. When testing $P$. crenulata, several inflorescences were used from one male tree and five female trees from California for the $3 \mathrm{~d}$ of testing. For P. trifoliata, inflorescences from six male and six female trees from Iowa were used for $3 \mathrm{~d}$. Bouquets were placed at least $1 \mathrm{~m}$ apart to limit fragrance contamination between pistillate and staminate inflorescences. To prevent order-of-presentation bias, half the volunteers smelled pistillate flowers first and then staminate, and half did the reverse. Panelists indicated their separate preferences for pistillate and staminate flowers on a survey with a nine-point hedonic scale $(1=$ dislike extremely, $9=$ like extremely). In addition, they were asked to explain their preferences by describing the fragrances.

\section{Statistical analysis}

For $P$. trifoliata only, differences between staminate and pistillate aromatic profiles were determined by analysis of variance (ANOVA) tests for individual chemicals and principal component analysis (PCA) with RStudio (version 4.0.3, car and factoextra packages; R Development Core Team, Vienna, Austria). PCA was used to give an overall summary of the variance between the sexes of the flowers using all the chemicals predicted. The data were expressed as a set of indices called principal components, which each explained a portion of the total variance in the data set. The numerous words generated by panelists during the descriptive assessments were categorized into groups based on similarities, and $\chi^{2}$ Fisher's exact tests (JMP Pro version 14; SAS Institute, Cary, NC) were used to determine response differences between species and sexes. Affective test preferences were converted to a scale of numbers for statistical analysis, with extremely dislike coded as 1 and extremely like coded as 9. Scores were compared with ANOVA and Tukey's honestly significant difference test (JMP Pro version 14).

\section{Results}

\section{Chemical analysis}

PCA confirmed differences between sexes of $P$. trifoliata $[P<$ 0.001 (Fig. 1)]. The first four principal components together explained $80 \%$ of the variance (Table 1). Almost all of the chemicals predicted contributed at least $4 \%$ to one of the first four principal components (Table 1). Although our purpose focused on differences between the sexes, our statistical analysis also accounted for differences in location (Fig. 1, Table 2). With the exception of cis-3-hexenyl butanoate and an unidentified terpene, all chemicals that differed between the sexes had higher peaks among the females (Table 2). Ethyl benzoate and estragole were present in female flowers only (Table 2).

\section{Descriptive test}

Volunteers developed vocabulary lists that differed by species $(P<0.01)$ and by sex for $P$. trifoliata only $[P<0.0001$ (Tables 3 and 4)]. Volunteers easily distinguished empty jars from those with flowers $(P<0.0001)$. Words most frequently used to describe the fragrance of pistillate and staminate flowers of $P$. crenulata were citrus, sweet, lime, banana, mint, and pungent (Table 5). Pistillate flowers of $P$. trifoliata were most commonly described with the words damp-earthy, spicy, sweet, and citrus (Table 4). Staminate flowers of $P$. trifoliata were most frequently described as light, fresh, and grassy (Table 5). 
Table 3. List of vocabulary that panelists used in the second session of the descriptive test to describe Ptelea crenulata. To simplify the panelists' descriptions for statistical comparison with a $\chi^{2}$ Fisher's exact test, the panelists' words were grouped into categories listed at the top of each column.

\begin{tabular}{|c|c|c|c|c|c|c|}
\hline Citrus & Clean chemical & Floral & Fruity & Other & Spices & Vegetative \\
\hline Citronella & Fresh & Daffodil & Fruity & Dark & Allspice & Airy \\
\hline Citrus & Latex & Dainty & Melon & Dull & Baked goods & Alfalfa \\
\hline $\begin{array}{l}\text { Citrusy-cleaning- } \\
\text { supplies }\end{array}$ & Medicinal & Floral & Passion fruit & Heavy & Basil & Bark-like \\
\hline Lemon grass & Menthol & Honey & Peaches & Light & Chai & Cardboard \\
\hline Lime & Sterile & Honeysuckle & $\begin{array}{r}\text { Overripe- } \\
\text { banana }\end{array}$ & Musky & Cinnamon & Earthy \\
\hline \multirow[t]{16}{*}{ Orange } & Toothpaste & Judd viburnum & & Pleasant & Cologne & Elf-like \\
\hline & & Lilac & & Sweet & Herbal & Fermented corn \\
\hline & & Lily & & Unpleasant & Licorice & $\begin{array}{l}\text { Fermenting, decaying, } \\
\text { wet plants }\end{array}$ \\
\hline & & Lily of the valley & & Urine & Masculine & Freshly cut wood \\
\hline & & Prairie flower & & Warm & Warm mint & Leafy \\
\hline & & Sweet nectar & & Yellow & Sweet & Mossy \\
\hline & & Tulip & & & Mint & Mowed grass \\
\hline & & Silky & & & Nutmeg & Musty \\
\hline & & & & & Pungent & Oaky \\
\hline & & & & & Sharp & Sawdust \\
\hline & & & & & Spices & $\begin{array}{l}\text { Stems-of-cut-roses-in- } \\
\text { water }\end{array}$ \\
\hline & & & & & Tea & Tropical \\
\hline & & & & & & Vegetation \\
\hline & & & & & & Wet \\
\hline & & & & & & Woody \\
\hline & & & & & & Woodsy \\
\hline
\end{tabular}

\section{Affective test}

For $P$. crenulata and $P$. trifoliata, respectively, $81.1 \%$ and $77.0 \%$ of survey responses were from volunteers who liked the floral fragrance (Fig. 2). Those who extremely liked the fragrance of $P$. crenulata described it as spring-like, sweet, fresh, floral, peppery, or summer-like. Volunteers extremely liked the fragrance of $P$. trifoliata because it was floral, lilac-like, jasminelike, citrus, candy-like, sweet, or slightly musky. Those who disliked the fragrance of $P$. crenulata described it as bitter, earthy, sour, skunky, sickly-sweet-medicinal, stale, Cannabis-like, fermented, eucalyptus-like, overwhelmingly fruity, similar to marigold leaves, or similar to wilting Matthiola incana. The fragrance of $P$. trifoliata was disliked because it was stinky, weedy, heavy, musky, urine-like, faintly manure-like, mustard-like, eucalyptus-like, or caustic.

ANOVA tests showed no difference in preference for pistillate or staminate flowers of either $P$. crenulata $(P<0.36)$ or $P$. trifoliata $(P<0.68)$. In the test for a preference for either pistillate or staminate flowers of $P$. crenulata, $27.7 \%$ of participants liked one and disliked or were indifferent to the other. Of those 33 participants, $54.5 \%$ preferred staminate flowers. With $P$. trifoliata, $26.1 \%$ liked one and disliked or were indifferent to the other. Of those 29 participants, 55.2\% also preferred staminate flowers.

No difference between mean scores pooled across sex was observed for different days of the panel for P. crenulata $(P<0.07)$

Table 4. List of vocabulary that panelists used in the second session of the descriptive test to describe Ptelea trifoliata. To simplify the panelists' descriptions for statistical comparison with a $\chi^{2}$ Fisher's exact test, the panelists' words were grouped into categories listed at the top of each column.

\begin{tabular}{|c|c|c|c|c|c|c|}
\hline Citrus & Clean chemical & Floral & Fruity & Other & Spices & Vegetative \\
\hline Citrus & Fresh & Floral & Fruity & Sweet & Cedar & Damp-earthy \\
\hline \multirow[t]{8}{*}{ Lemon grass } & Clean linen & & Ripe banana & Pleasant & Basil & Dark leafy lettuce \\
\hline & Mouthwash & & Bubble gum & Light & Herbal & Prairie \\
\hline & & & Pineapple & Delicate & Sharp & Grassy \\
\hline & & & & & Masculine & Meadow \\
\hline & & & & & Spicy & Tree leaves \\
\hline & & & & & Menthol & \\
\hline & & & & & Minty & \\
\hline & & & & & Cinnamon & \\
\hline
\end{tabular}


Table 5. Panelists' most frequently chosen descriptors from the second session of the descriptive panel for pistillate and staminate flowers of Ptelea crenulata and Ptelea trifoliata.

\begin{tabular}{|c|c|c|c|c|c|c|c|}
\hline \multicolumn{4}{|c|}{ P. crenulata } & \multicolumn{4}{|c|}{ P. trifoliata } \\
\hline Pistillate & Frequency $(\%)$ & Staminate & Frequency $(\%)$ & Pistillate & Frequency $(\%)$ & Staminate & Frequency $(\%)$ \\
\hline Citrus & 9 & Citrus & 7.3 & Damp-earthy & 7.14 & Light & 7.41 \\
\hline Lime & 7.5 & Sweet & 7.3 & Spicy & 7.14 & Fresh & 6.48 \\
\hline Sweet & 6 & Banana & 5.7 & Sweet & 6.35 & Grassy & 6.48 \\
\hline Banana & 4.5 & Lime & 4.9 & Citrus & 5.56 & Pleasant & 6.48 \\
\hline Mint & 4.5 & Pungent & 4.1 & Pleasant & 5.56 & Damp-earthy & 5.56 \\
\hline Earthy & 4.5 & Heavy & 4.1 & Dark leafy lettuce & 4.76 & Floral & 5.56 \\
\hline \multirow[t]{2}{*}{ Floral } & 3.8 & Musty & 4.1 & Fresh & 4.76 & Sweet & 5.56 \\
\hline & & & & Banana & 4.76 & & \\
\hline
\end{tabular}

or $P$. trifoliata $(P<0.15)$, indicating that the floral aromas were consistent throughout the studies.

\section{Discussion}

The floral fragrance of $P$. crenulata and $P$. trifoliata was appealing to most panelists in the affective analysis, and reactions to pistillate and staminate flowers were similar. The differences identified by panelists in the descriptive analysis between the fragrances of pistillate and staminate flowers of $P$. trifoliata were consistent with the differences in peak heights observed in the GCs (Tables 2 and 5). The PCA that summarized most of the variance contributed to the volatile compounds also confirmed a difference between the sexes of $P$. trifoliata (Fig. 1, Table 1). The fragrances of individual chemicals predicted correspond closely to panelists' descriptions (Tables 2 and 5). Many of the compounds are described as floral, fruity, herbal, minty, and spicy; linalool is associated with citrus (Table 2). $\beta$-myrcene, which smells balsamic, fruity, geranium-like, herbal, and musty, may be responsible for the musky odor that panelists described, whereas 1,3,8-p-menthatriene, sabinene, and $\delta$-cadinene, which smell like turpentine and medicine, might explain the medicinal descriptions (Tables 2-4). Pistillate and staminate flowers of $P$. trifoliata had nearly identical aromatic compounds, although only pistillate flowers emitted ethyl benzoate and estragole. When concentrations differed, they were higher in pistillate than

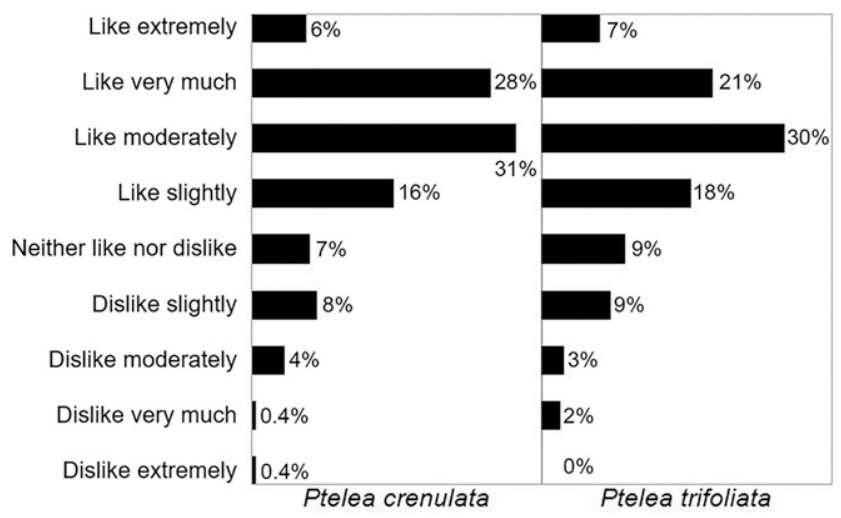

Fig. 2. Distribution of affective panel responses to hedonic-scale survey for preference of fragrance of Ptelea crenulata and Ptelea trifoliata. Each volunteer filled out a survey for both pistillate and staminate flowers, which are combined in this figure. For P. crenulata, 119 panelists participated, and 111 volunteers participated in the panel for $P$. trifoliata. in staminate fragrance profiles, except in the case of cis-3-hexenyl butanoate and an unidentified terpene.

Eugenol, methyl salicylate, estragole, anethole, myrcene, ocimene, linalool, caryophyllene, bourbonene, and farnesene occur in many plants and were emitted from the flowers of $P$. trifoliata (Table 1) (Knudsen and Tollsten, 1993). The floral aromatic compounds of this species include several chemicals known from flowers of other members of the Rutaceae (Fadamiro, 2010; Loper, 1972; Renner, 1962). Linalool, myrcene, caryophyllene, and $\gamma$-Muurolene are components of the fragrance of Zanthoxylum clava-herculis (Fadamiro, 2010). Flowers of Citrus depressa also emitted linalool and myrcene, as well as ocimene (Loper, 1972). Linalool is a major component of the floral extract of Citrus sinensis, which also contains myrcene and ocimene (Grajales-Conesa et al., 2012). The floral extract of Citrus limon includes myrcene, trans-ocimene, caryophyllene, $\alpha$-farnesene, and p-cubebene (Grajales-Conesa et al., 2012). Flowers of Boronia megastigma emit small concentrations of myrcene from the calyx and nectaries (MacTavish et al., 2000). Major components of the bud stage are caryophyllene and humulene, whereas concentrations of myrcene and ocimene are found in flowers at anthesis (MacTavish et al., 2000).

It is not surprising that similar compounds are shared among P. trifoliata and other Rutaceae because our panelists chose the word citrus to describe the floral aromas of both species of Pte$l e a$, and the fragrance of $P$. trifoliata had previously been described as possessing a strong citrus aroma (Table 3) (Nokes, 2001; Wasson, 2001). Several of the compounds predicted in P. trifoliata, such as E,E-2,6-dimethyl-1,3,5,7-octatetraene, methyl salicylate, eugenol, methyleugenol, estragole, linalool, myrcene, trans $\beta$-ocimene, and $\alpha$-farnesene, are emitted from flowers of Hyacinthus, which may explain why Knuth (1908) compared $P$. trifoliata to hyacinths; however, these chemicals are either equal to or higher in pistillate flowers than in the staminate, whereas Knuth (1908) said the staminate flowers of $P$. trifoliata had the stronger scent (Table 1).

A minority of panelists disliked the fragrance of both species of Ptelea, which corresponds with the descriptions of Elmore and Janish (1976) and Kurz (1997) (Fig. 2). Two of the 15 members of the descriptive panel for $P$. crenulata used the word urine to describe the fragrance, which may be the same scent that Kurz (1997) called the bobcat scent (Table 3). The panelists from the descriptive study most frequently included the seemingly contrasting citrus, fruity, musty, and pungent in their description of $P$. crenulata; sweet, spicy, and damp-earthy in pistillate $P$. trifoliata; and light, fresh, floral, and damp-earthy in staminate $P$. trifoliata. These contrasting scents reported by our 
panelists from the same flowers attest to the complexity of these fragrances. The aromatic chemical profiles of staminate and pistillate flowers of $P$. trifoliata differed; however, results from our affective panel indicate that differences in the ability of individual humans to discern these differences may be more important for human preference than are differences in chemical composition (Tables 2 and 5, Figs. 1 and 2).

Setzer and Satyal (2019) recently analyzed the composition of essential oil obtained from the flowers of $P$. trifoliata and reported many of the same components as found in our headspace analysis, including linalool, methyleugenol, caryophyllene, germacrene $\mathrm{D}$, humulene, $\gamma$-murolene, $\beta$-myrcene, $\beta$-ocimene, $\beta$-bourbonene, anethole, ylangene, and $\alpha$-farnesene. Notably, limonene, a monoterpene present in many Rutaceae and other flowering-plant families, is not in the floral aroma of $P$. trifoliata (Fadamiro, 2010; Knudsen and Tollsten, 1993; Loper, 1972; MacTavish et al., 2000). Limonene was also absent from the leaf essential oil of $P$. trifoliata, but present in its bark oil (Steinberg et al., 2017).

When concentration differences in the components of the fragrances of the staminate and pistillate flowers of $P$. trifoliata did occur, most chemicals had higher concentrations in pistillate flowers, although cis-3-hexenyl butanoate and an unidentified terpene were exceptions (Table 2). Only pistillate flowers emitted ethyl benzoate and estragole (Table 2). Sex-based differences in the aromatic profiles of flowers of other species have been reported. For example, the pistillate flowers of Ficus fistulosa emitted several compounds that were not emitted from staminate flowers; however, other fig species showed the opposite results (Grison et al., 1999). These findings contrast with those reported for Silene latifolia, which emits more fragrant aromatics from staminate than from pistillate flowers (Waelti et al., 2009). Also, linalool and its oxides were unique to staminate flowers of L. nobilis, making the staminate flowers more aromatically complex than the pistillate (Flamini et al., 2002).

Although no clear aromatic trend presents itself among dioecious species, perhaps the strategy for $P$. trifoliata is to entice pollinators with a more complex and stronger fragrance to its pistillate flowers that do not offer a pollen reward. Higher concentrations among most of the terpenes in the pistillate flowers may also function by adding extra protection for the female organs and especially their developing seeds (Gershenzon and Croteau, 1992).

Scent is a key attractant of pollinators, and the flowers of $P$. trifoliata are mostly visited by bees, wasps, and flies (Ambrose et al., 1985; Pichersky and Gershenzon, 2002). It might be possible to postulate which chemicals in the fragrance profile of $P$. trifoliata attract bees, wasps, and flies by identifying which chemicals they have in common with other flowers known to attract bees, wasps, and flies. The spicy-floral-scented, bee-pollinated Cattleya labiata contains mostly caryophyllene, as well as myrcene, ocimene, (E,E)-2,6-dimethyl-1,3,5,7-octatetraene, humulene, germacrene $\mathrm{D}$, and jasmone; all of which are present in P. trifoliata (Table 1) (Kaiser, 1993). Bees from the tribe Meliponini are strongly attracted to floral extracts of $C$. sinensis and $C$. limon, which share aromatic compounds with P. trifoliata (Table 1) (Grajales-Conesa et al., 2012). Dictamnus albus, which has myrcene and limonene in its fragrance, is pollinated by insects from bee, fly, and wasp taxa (Renner, 1962; Sgolastra et al., 2016).
Genes linked to the expression of floral aromatics have been identified. In Clarkia breweri, genes have been isolated that code for enzymes that synthesize linalool, methyl eugenol, methyl isoeugenol, benzyl acetate, and methyl salicylate (Pichersky and Gershenzon, 2002). Scent formation is regulated in floral epidermal cells, especially in the petals (Pichersky and Gershenzon, 2002). In the case of Antirrhinum majus, the concentration of the enzyme that produces linalool is higher on the parts of the petal closest to the nectar source, suggesting linalool may guide insects to the nectar (Pichersky and Gershenzon, 2002).

In conclusion, this research provides the first analysis of floral aroma of $P$. crenulata and indicates that differences between staminate and pistillate flowers of $P$. trifoliata and differences in how humans perceive the volatiles emitted from these flowers, account for prior negative and positive descriptions. The complex and generally favorable floral fragrance of pistillate and staminate flowers of $P$. crenulata and $P$. trifoliata plays an ecological role by attracting pollinating insects and enhances the horticultural value of these trees. Both sexes and species can be recommended as ornamentals because of their elegant flowers, glossy leaves, distinctive samara fruits, cold hardiness, support for insects, and floral fragrance. Especially in the case of $P$. trifoliata, which has a wide distribution, further research could compare the effect of genetic variation among different regions on floral fragrance and human preference.

\section{Literature Cited}

Acree, T. and H. Arn. 2004. Flavornet and human odor space. 25 Feb. 2021. <http://flavornet.org/>.

Ambrose, J.D., P.G. Kevan, and R.M. Gadawski. 1985. Hop tree (Ptelea trfoliata) in Canada: Population and reproductive biology of a rare species. Can. J. Bot. 63:1928-1935, https://doi.org/10.1139/b85-272.

Bailey, V.L. 1962. Revision of the genus Ptelea (Rutaceae). Brittonia 14:1-45, https://doi.org/10.2307/2805316.

Cairncross, W.E. and L.B. Sjöström. 1950. Flavor profile - A new approach to flavor problems. Food Technol. 4:308-311. ISSN: 00156639.

Cuchet, A., P. Jame, A. Anchisi, F. Schiets, C. Oberlin, J. Lefevre, E. Carenini, and H. Casabianca. 2019. Authentication of the naturalness of wintergreen (Gaultheria genus) essential oils by gas chromatography, isotope ratio mass spectrometry and radiocarbon assessment. Ind. Crops Prod. 142:111873, https://doi.org/10.1016/j.indcrop.2019.111873.

Dirr, M.A. 1998. Manual of woody landscape plants: Their identification, ornamental characteristics, culture, propagation, and uses. Stipes Publ., Champaign, IL.

Elmore, F.H. and J.R. Janish. 1976. Shrubs and trees of the southwest uplands. Southwest Parks and Monument Assoc., Globe, AZ.

Fadamiro, H. 2010. Antennal electrophysiological responses of the giant swallowtail butterfly, Papilio cresphontes, to the essential oils of Zanthoxylum clava-herculis and related plants. Chemoecology 20:25-33, https://doi.org/10.1007/s00049-009-0039-1.

Flamini, G., P.L. Cioni, and I. Morelli. 2002. Differences in the fragrances of pollen and different floral parts of male and female flowers of Laurus nobilis. J. Agr. Food Chem. 50:4647-4652, https://doi. org/10.1021/jf020269x.

Flavor \& Extract Manufacturers Association. 2021. Flavor ingredient library. 25 Feb. 2021. < http://Femaflavor.org/flavor-library $>$.

Gershenzon, J. and R. Croteau. 1992. Terpenoids, p. 165-219. In: G.A. Rosenthal and M.R. Berenbaum (eds.). Herbivores: Their interactions with secondary plant metabolites. Vol. 1: The chemical participants. 2nd ed. Academic Press, San Diego, CA.

Giovannini, A., M. Laura, B. Nesi, M. Savona, and T. Cardi. 2021. Genes and genome editing tools for breeding desirable phenotypes in 
ornamentals. Plant Cell Rep. 40:461-478, https://doi.org/10.1007/ s00299-020-02632-x.

Grajales-Conesa, J., V.M. Ramirez, L. Cruz-López, and D.S. Guillén. 2012. Effect of Citrus floral extracts on the foraging behavior of the stingless bee Scaptotrigona pectoralis (Dalla Torre). Rev. Bras. Entomol. 56:76-80, https://doi.org/10.1590/S0085-56262012000100012.

Grison, L., A.A. Edwards, and M. Houssaert-McKey. 1999. Interspecies variation in floral fragrances emitted by tropical Ficus species. Phytochemistry 52:1293-1299, https://doi.org/10.1016/S0031-9422(99)00411-2.

Harrison, T.L. and M.R. Berenbaum. 2005. Rutaceae-feeding Agonopterix Hubner (Lepidoptera: Elachistidae) in Illinois. Proc. Entomol. Soc. Washington 107:162-175. ISSN: 0013-8797.

Harvey, J.H. 1981. A Scottish botanist in London in 1766. Gard. Hist. 9(1):40-75, https://doi.org/10.2307/1586706.

Herrmann, K.M. and L.M. Weaver. 1999. The shikimate pathway. Annu. Rev. Plant Physiol. Plant Mol. Biol. 50:473-503, https://doi. org/10.1146/annurev.arplant.50.1.473.

Kaiser, R.A.J. 1993. Bioactive volatile compounds from plants. Am. Chem. Soc., Washington, DC.

Knuth, P. 1908. Handbook of flower pollination. Vol. 2 (Translated by J. R. Ainsworth.) Clarendon Press, Oxford, UK.

Kurz, D. 1997. Shrubs and woody vines of Missouri. Conservation Commission of the State of Missouri, Jefferson City, MO.

Knudsen, J.T. and L. Tollsten. 1993. Floral scents-A checklist of volatile compounds isolated by head-space techniques. Bot. J. Linn. Soc. 113:263-284, https://doi.org/10.1016/0031-9422(93)85502-I.

Lancaster, R. 1995. Ptelea trifoliata 'Aurea'. Garden 120(1):12-13.

Lichtenthaler, H.K. 1998. The plant's 1-deoxy-d-xylulose-5-phospate pathway for biosynthesis of isoprenoids. Fett/Lipid 100:128-138, https://doi.org/10.1002/(SICI)1521-4133(19985)100:4/5<128:AIDLIPI128>3.0.CO;2-D.

Lim, J. 2011. Hedonic scaling: A review of methods and theory. Food Qual. Prefer. 22:733-747, https://doi.org/10.1016/j.foodqual.2011.05.008.

Loper, G.M. 1972. Medicago sativa and Citrus depressa flower volatiles. Phytochemistry 11:1865.

MacTavish, H.S., N.W. Davies, and R.C. Menary. 2000. Emission of volatiles from brown boronia flowers: Some comparative observations. Ann. Bot. 86:347-354, https://doi.org/10.1006/anbo.2000.1194.

McMinn, H.E. 1989. An illustrated manual of California shrubs. J.W. Stacey, San Francisco, CA.

Menzel, R., I. Erber, and T. Masuhr. 1974. Learning and memory in the honeybee, p. 195-217. In: L. Barton Browne (ed.). Experimental analysis of insect behavior. Springer, Berlin, Germany.

Nokes, J. 2001. How to grow native plants of Texas and the Southwest. Univ. Texas Press, Austin, TX.

Pichersky, E. and J. Gershenzon. 2002. The formation and function of plant volatiles: Perfumes for pollinator attraction and defense. Curr. Opin. Plant Biol. 5:237-243, https://doi.org/10.1016/S1369-5266(02)00251-0.

Renner, W. 1962. Contributions to the knowledge of the biogenesis of secondary plant substances in Dictamnus albus L. Pharmazie 17:763-776.
Schiesti, F.P. and M. Ayasse. 2001. Post-pollination emission of a repellent compound in a sexually deceptive orchid: A new mechanism for maximizing reproductive success? Oecologia 126:531-534, https://doi. org/10.1007/S004420000552.

Schiesti, F.P., M. Ayasse, H.F. Paulus, C. Lofstedt, B.S. Hansson, F. Ibarra, and W. Francke. 1999. Orchid pollination by sexual swindle. Nature 399:421-422, https://doi.org/10.1038/20829.

Schnetter, B. 1972. Experiments on pattern discrimination in honey bees, p. 195-201. In: R. Wehner (ed.). Information processing in the visual system of arthropods. Springer, Berlin, Germany.

Scriber, J.M. and R.V. Dowell. 1991. Host plant suitability and a test of the feeding specialization hypothesis using Papilio cresphontes (Lepidoptera: Papilionidae). Great Lakes Entomol. 24(1):27-37.

Setzer, W.N. and P. Satyal. 2019. Essential oil compositions of male and female flowers of Ptelea trifoliata. Amer. J. Essential Oils Natural Prod. 7(4):18-22. ISSN: 2321-9114.

Sgolastra, F., A. Fisogni, M. Quaranta, G. Bogo, L. Bortolotti, and M. Galloni. 2016. Temporal activity patterns in a flower visitor community of Dictamnus albus in relation to some biotic and abiotic factors. Bull. Insectol. 69:291-300. ISSN: 1721-8861.

Steinberg, K.M., P. Satyal, and W.M. Setzer. 2017. Bark essential oils of Zanthoxylum clava-herculis and Ptelea trifoliata: Enantiomeric distribution of monoterpenoids. Nat. Prod. Commun. 12:961-963, https://doi.org/10.1177/1934578X1701200632.

Stewart, A.J. 2021. Horticultural and ecophysiological studies of Ptelea trifoliata and Ptelea crenulata. Iowa State Univ., Ames, PhD Diss.

Stone, H., J. Sidel, S. Oliver, A. Woolsey, and R.C. Singleton. 1974. Sensory evaluation by quantitative descriptive analysis. Food Technol. 28(11):24-34, https://doi.org/10.1520/mnl1320170005.

Sword, G.A. and E.B. Dopman. 1999. Developmental specialization and geographic structure of host plant use in a polyphagous grasshopper, Scistocerca emarginata (=lineata) (Orthoptera: Acrididae). Oecologia 120:437-445, https://doi.org/10.1007/s004420050876.

Taiz, L. and E. Zeiger. 2010. Plant physiology. 5th ed. Sinauer Assoc., Sunderland, MA.

Theis, N. 2006. Fragrance of canadian thistle (Cirsium arvense) attracts both floral herbivores and pollinators. J. Chem. Ecol. 32:917-927, https://doi.org/10.1007/s10886-006-9051-x.

Waelti, M.O., P.A. Page, A. Widmer, and F.P. Schiestl. 2009. How to be an attractive male: Floral dimorphism and attractiveness to pollinators in a dioecious plant. Evol. Biol. 9:190, https://doi.org/10.1186/ 1471-2148-9-190.

Waliczek, T.M., D. Byrne, and D. Holeman. 2018. Opinions of landscape roses available for purchase and preferences for the future market. HortTechnology 28:807-814, https://doi.org/10.21273/HORTTECH04175-18. Wasson, E. 2001. Trees and shrubs: Illustrated A-Z of over 8500 plants. Global Book Publ., Willoughby, NSW, Australia.

Yang, E.S.M. and W.L. Applequist. 2015. Phenetic analyses and revised classification of the Ptelea trifoliata complex (Rutaceae). West. N. Amer. Nat. 75:406-428, https://doi.org/10.3398/ 064.075.0401. 